\title{
ALIRAN PEMIKIRAN USHUL FIQH DAN PENGARUHNYA TERHADAP PENDEKATAN HUKUM ISLAM
}

\author{
Hanif Aidhil Alwana
}

Pascasarjana IAIN Bukittinggi

Email: hanif.alwana18@gmail.com

\begin{tabular}{|l|l|l|}
\hline Submit: 07-09-2020 & Direvisi: 10-11-2020 & Dipublish: 18-12-2020 \\
\hline
\end{tabular}

\begin{abstract}
Law is the result of Fuqaha's ijtihad regarding an act of mukallaf, in its understanding Islamic law is derived from the al-Quran and Sunnah. Although the existence of the al-Qur'an and the Sunnah is not in doubt, the understanding of law from these sources often experiences ikhtilaf (differences) of opinion, besides this the risk of causing divisions in society, these problems are influenced by schools of legal thought. This paper will describe the history of these schools of thought and their relevance in establishing law. The method used was descriptive analysis, with a qualitative approach based on the content (content analysis) of previous writings. In this paper, it is found that the difference in legal opinion is influenced by the way of thinking of the mujtabid which is divided into mutakallimin schools which are identical to understanding the legal text; fuqaha with the style of rules and legal reasons extracted from the law-making text (syari) or also termed a contextual style; and a combination that seeks to combine the two types of legal understanding, this gives birth to different legal features. This is the scientific treasure of Islamic law which must be developed in the future to always exist in answering legal problems in the future.
\end{abstract}

Kata kunci: Aliran Pemikiran Hukum Islam, ushul fiqh, ijtihad

\section{PENDAHULUAN}

$S$ ejarah Islam mencatat, bahwa embrio perbedaan pendapat yang akhirnya melahirkan aliran atau mazhab dimulai pada perbedaan umat dalam masalah politik (S Elwa, 1983: 33-34), dari sinilah kemudian masalahnya berkembang menjadi masalah teologi, hukum, dan kepemimpinan di mana terdapat perbedaan antara yang satu dengan lainnya. Secara khusus hal ini kemudian membawa pengaruh pada munculnya aliran-aliran dalam bidang hukum Islam (Ushul Fiqh) (Abbas, 2010: 19), termasuk perbedaan pandangan seperti mazhab Zahiri dalam memposisikan dan memaknai lafaz atau teks al-Qur’an dan Sunnah.
Al-Qur`an sebagai sumber hukum primer (J. Moleong, 1989: 17) kajian hukum Islam diturunkan oleh Allah SWT kepada manusia sebagai petunjuk atau pedoman hidup (al-huda linnas) (Hakiki, 2016: 10), sekaligus sebagai petunjuk yang sempurna dan paripurna. Al-Qur`an yang diturunkan kepada nabi Muhammad SAW sebagai penutup para nabi, merupakan legitimasi konkret yang menerangkan bahwa al-Qur`an benar sebagai kitab (hukum/petunjuk) yang tepat, serta syiar yang baik (rahmah/hak) untuk kehidupan manusia khususnya. (Imron, 2008: 1) Apalagi eksistensi alQur`an sering diistilahkan dengan shahih likulli zaman wa makan. (Ismail, 2016: 4546) 
Untuk memahami kandungan alQur`an sebagai manifestasi (Bay, 2012: 142) hidup di tengah-tengah masyarakat, dibutuhkan fungsi akal yang memadai. Hal ini sangat mempengaruhi pendekatan terhadap pemahaman hukum Islam. Dalam al-Qur`an surat al-A`raf ayat 179 Allah SWT berfirman:

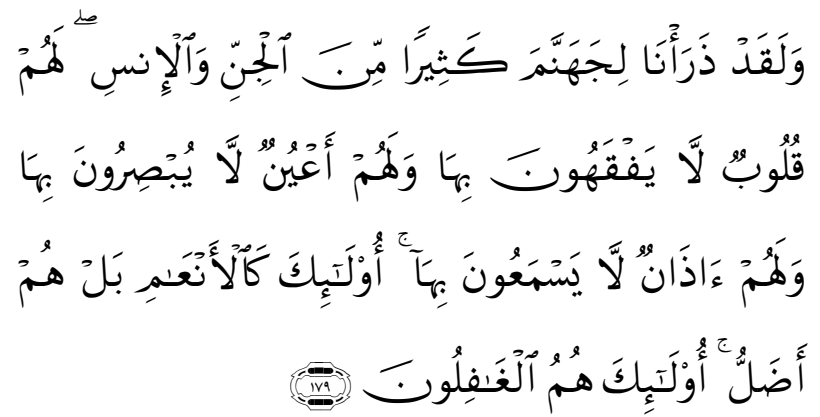

"Dan sesungguhnya Kami jadikan untuk (isi neraka Jahannam) kebanyakan dari jin dan manusia, mereka mempunyai hati, tetapi tidak dipergunakannya untuk memahami (ayat-ayat Allah) dan mereka mempunyai mata (tetapi) tidak dipergunakannya untuk melihat (tanda-tanda kekuasaan Allah), dan mereka mempunyai telinga (tetapi) tidak dipergunakannya untuk mendengar (ayatayat Allah). Mereka itu sebagai binatang ternak, bahkan mereka lebih sesat lagi. Mereka itulah orang-orang yang lalai". (QS. Al-A'raf [7]: 179)

Maksud ayat di atas adalah upaya yang sering diistilahkan sebagai Ijtihad, ijtihad adalah usaha sungguh-sungguh yang dilakukan oleh orang tertentu sebagai mujtahid (Rusli, 1999: 41), dalam komentar Ibnu Katsir disebutkan sebagai bukti syukur manusia atas karunia indera dari Allah SWT. (Ibnu Katsir, 2015)

Hal ini dijelaskan Allah SWT bahwa manusia sebagai bentuk terbaik penciptaan makhluk. Dalam al-Qur`an surat atTin ayat 4 Allah SWT berfirman:

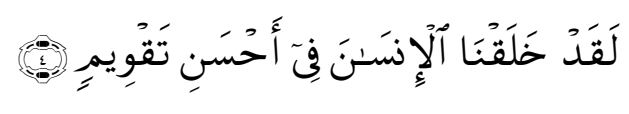

"Sesungguhnya Kami telah menciptakan manusia dalam bentuk yang sebaik-baiknya". (QS. at-Tin [95]: 4)

Di sisi lain, penciptaan terbaik itu dibuktikan dengan dikaruniainya manusia dengan unsur lahir (jasmani) dan unsur bathin (rohani) (Malarangan, 2008: 40). Sehingga, manusia pada umumnya sudah diberikan indera (alat) untuk senantiasa mendalami pesan-pesan Allah SWT, meskipun setiap pemahaman yang dilakukan oleh mujtahid disepakati para Fuqaha bersifat dzanni (mempunyai makna keboleh jadian).

Ilmu Ushul Fiqh mendukung perkembangan pemikiran hukum Islam yang pada dasarnya diinisiasi oleh kelompokkelompok seperti Syi`ah, Dzahiriah, dan Sunni, juga mendasarkan kajiannya pada ilmu Ushul Fiqh. Imam al-Ghazali menjadikan ilmu ini sebagai syarat mutlak, bahkan menurutnya untuk memahami hukum-hukum Allah SWT itu hanya bisa ditemukan bila menggunakan pendekatan ilmu Ushul Fiqh. (Mth, 2005: 155-156) Penekanan ini sangat beralasan, karena bilmana ilmu Ushul Fiqh sudah dipahami, akan memberikan batasan yang tepat untuk terhindar dari kesalahan pemahaman terhadap syari at Allah SWT.

Aliran-aliran Ijtihad menurut para ulama didasarkan pada dua hal, yaitu pertama terkait dengan kaidah-kaidah kebahasaan (tesktual), dan yang kedua adalah kaidah-kaidah syar iyyah (kontekstual). Dalam istilah lain, pendekatan yang digunakan pada kaidah kebahasaan ini berorientasi pada pemahaman teks alQur'an dan as-Sunnah, sedangkan orientasi yang dikemukakan oleh seorang mujtahid pada kaidah syariyyah ini 
adalah untuk mencari tujuan ditetapkannya hukum itu oleh Syari (pembuat hukum), atau sering juga disebut sebagai tinjauan maqashid as-syari ah.

Dari apa yang penulis uraikan di atas, tampak jelas bahwa aliran-aliran pemahaman hukum Islam dilatar belakangi oleh munculnya corak dan sudut pandang tertentu dalam memahami hukum-hukum Allah STW. Sehingga, dalam tulisan ini penulis akan menjabarkan lebih lanjut aliran-aliran tersebut. Batasan pembahasan ini ialah pertama menjabarkan sejarah aliran-aliran dalam ilmu Ushul Fiqh, dan yang kedua pengaruh aliran-aliran dalam ilmu Ushul Fiqh serta relevansinya dalam pendekatan hukum Islam.

\section{METODE PENELITIAN}

\section{Jenis Penelitian}

Dalam tulisan ini, kajian yang dilakukan adalah jenis penelitian kualitatif dengan pendekatan sajian analisis deskriptif terhadap kajian-kajian kepustakaan. Sehingga, secara umum tulisan ini ialah jenis penelitian kepustakaan (library research), maksudnya mengumpulkan data-data yang tersaji pada literatur sebagai sumber analisis aliran-aliran pemahaman hukum Islam.

\section{Teknik Pengumpulan Data}

Data literatur penelitian ini penulis lakukan dengan teknik analisis isi (content) (J. Moleong, 1989: 76), yang dinyatakan dengan kata atau kalimat. Tulisan ini menggunakan sumber primer buku-buku, seperti Abdul Wahhab Khallaf, Ilmu Ushul al-Fiqh, (Jakarta:
Dewan Dakwah Islamiyah Indonesia, 1970); Syaikh al-Jami al-'Azam Muhammad al-Tahir ibn 'Asyir, Maqashid al-Syariat al- Islamiyyah, (Beirut: Dar Ibn Hazm, 1996); Afifi Fauzi Abbas, Baik Dan Buruk Dalam Perspektif Ushul Figh, (Ciputat Timur: ADELINA Bersaudara, 2010); Busyro, Dasar-Dasar Filosofis Hukum Islam, (Ponorogo: Wade, 2017); Busyro, Maqashid al-Syariah, (Ponorogo, Wade, 2017), dan fenomena pendekatan aliran pembaharuan hukum Islam yang bersumber dari literatur kekinian.

\section{SEJARAH MUNCULNYA ALIRAN- ALIRAN DALAM ILMU USHUL FIQH}

Berawal dari peristiwa wafatnya Rasulullah SAW pada tahun $632 \mathrm{M}$. Umat Islam pada waktu itu masih kecil dan sedikit jumlahnya. Mereka terdiri dari masyarakat Arab yang mendiami semenanjung Arabia, terutama di kota Makkah dan Madinah. Contoh persoalan yang dihadapi ketika itu ialah: soal siapakah yang nantinya akan menggantikan Rasulullah sebagai pemimpin agama dan kepala negara, sementara al-Qur`an tidak memberi petunjuk tentang hal itu, ditambah tidak ada pesan nabi yang secara langsung menerangkan tentang siapa yang akan menggantikan beliau. (S Elwa, 1983: 33-34)

Jalan keluar yang ditempuh oleh umat Islam pada waktu itu melakukan musyawarah (ijtihad), yaitu antara kelompok Anshar dan kaum Muhajirin. Abu Bakar as-Shiddiq dari kelompok Muhajirin menghendaki khalifah dari kalangan suku Quraisy, hal ini didasarkan atas kepeloporan mereka dan tradisi kepemimpinan yang dipegang suku ini 
150

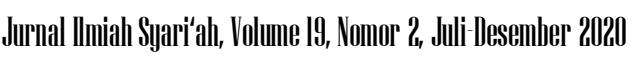

disamping tidak mungkin umat Islam dipimpin oleh dua orang khalifah, karena hal tersebut justru hanya akan melemahkan persatuan dan kesatuan umat Islam.

Musyawarah (Amin, 2014: 1) yang dilakukan Anshar dan Muhajirin inilah yang menetapkan bahwa Abu Bakar sebagai khalifah pengganti Rasulullah, ia terpilih sebagai khalifah berdasarkan argumentasi, al-Immatu Minal Quraisy الأئمة dan argumentasi lain yang memberikan gambaran bahwa Abu Bakar adalah orang yang sering menggantikan kedudukan Rasulullah ketika beliau berhalangan, ini pulalah yang kemudian dijadikan doktrin oleh kelompok Sunni selama berabad-abad lamanya untuk memilih khalifah dari suku Quraisy. Lain halnya dengan pandangan kelompok Syi ah, mereka berpendapat bahwa yang paling berhak menggantikan nabi adalah salah satu keluarga, saudara yang terdekat dengan nabi, sehingga mereka menetapkan Ali Bin Abi Thalib yang paling berhak untuk itu. (M. A. Zahrah, 1996: 54)

Dari persoalan di atas kemudian berkembang menjadi teori negara dan pemerintahan dalam Islam sedemikian rupa menjadi persoalan ijtihad karena alQur'an tidak menjelaskan secara tegas meskipun ada isyarat tentang musyawarah seperti dijelaskan dalam surat asySyura ayat 38:

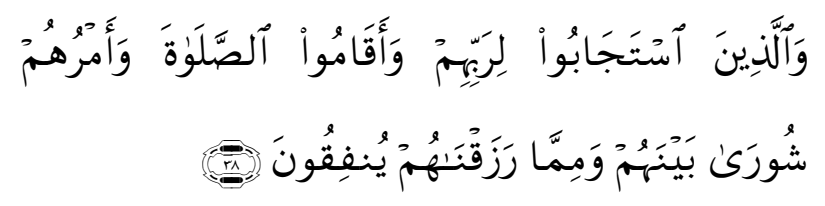

"Dan (bagi) orang-orang yang menerima (mematuhi) seruan Tuhannya dan mendirikan shalat, sedang urusan mereka (diputuskan) dengan musyawarat antara mereka; dan mereka menafkahkan sebagian dari rezki yang Kami berikan kepada mereka". (QS. Asy-Syura [42]: 38)

Kisah dinamika pada masa kekhalifahan ketiga dan keempat tidak hanya membawa implikasi politik yang tajam akan tetapi meningkat kepada persoalan persoalan teologis yang kemudian melahirkan 4 aliran besar yaitu: Khawarij, Murjiah, Mu'tazilah, dan Syiah.

Timbullah perbedaan tentang boleh tidaknya membunuh sesama muslim, kemudian apakah hal tersebut termasuk dosa besar atau tidak. Berkaitan dengan hal ini muncul berbagai tanggapan di kalangan kaum muslimin, apakah pelaku dosa besar ini masih tetap dianggap sebagai seorang beriman, ataukah mereka sudah kafir, atau hanya dianggap sebagai orang munafik, atau fasik. Jadi tragedi politik seperti diuraikan, telah memicu munculnya berbagai upaya untuk mencari justifikasi terhadap berbagai pemikiran dan sikap politik yang ada dan ini pun kemudian mendorong lahirnya aliranaliran teologi dalam Islam. (al-Zuhaily, 2002: 303)

Bila dicermati secara mendalam dan dikaitkan ke bidang hukum atau fiqh maka kondisi tersebut sama dengan bidang politik, bahkan sering ditemui dalam sejarah pembinaan dan perkembangan hukum Islam. (Busyro, 2009: 22-23)

Umatpun berupaya menyelesaikan persoalannya sendiri berdasarkan alQuran dan as-Sunnah (Toriquddin, 2014, hlm. 34), ternyata tidak semua persoalan yang timbul dapat dikembalikan kepada al-Quran dan as-Sunnah. Secara eksplisit untuk masalah-masalah yang tidak ditemukan jawabannya dalam kedua 
sumber hukum tersebut, para ulama melakukan ijtihad.

Setiap daerah memiliki ciri dan corak fiqh sendiri sesuai dengan situasi dan kondisi masyarakat di daerah tersebut. Dari perkembangan ini dikenal adanya Madrasah al-Iraq atau Madrasah al-Kufah, di sisi lain ada pula Madrasah al-Madinah dan Makkah. (Busyro, 2014: 45-50) Dalam sejarah perkembangannya Madrasah Iraq atau Kuffah ini disebut juga dengan Ahlul Rayi, sedangkan Madrasah Madinah dan Makkah disebut juga dengan Madrasah al-Hijaz atau dikenal dengan sebutan Ahlul Hadits. Kelompok Ahlul hadits dan kelompok Ahlul Ra yi ini pada waktu itu dalam sejarah ditemukan banyak memperdebatkan tentang dasar rasional bagi pengambilan keputusan hukum mereka. (Sabiq, 1977: 27)

Kelompok pertama meyakini bahwa aliran kalam yang dianut oleh seorang teolog berkecenderungan untuk mempengaruhi pemikiran hukumnya yang beraliran kalam Asy'ariyah (Suherman, t.t: 11), misalnya kecenderungan mendahulukan Nash dari pada akalnya sebaliknya ahli fiqh yang beraliran kalam mu'tazilah kecenderungan mendahulukan akal dari pada wahyu. Sementara itu kelompok kedua berpendapat bahwa pemikiran dalam bidang hukum tidak dipengaruhi oleh aliran kalam yang dianut oleh ahli fiqh tertentu bagi kelompok ini fiqh yang beraliran kalam Asy'ariyah maupun Mu'tazilah tidaklah mengembangkan teori-teori fiqhnya berdasarkan aliran kalam yang mereka anut, mereka memiliki pemikiran hukum ilmu Ushul Fiqh masing-masing.

Meskipun pada mulanya tidak nampak secara jelas tentang adanya suatu kaitan antara kedua perkembangan ini yaitu perkembangan ilmu kalam di satu pihak, dan ilmu fiqh atau Ushul Fiqh di pihak lain. Namun demikian dapat diasumsikan bahwa pemikiran ahli-ahli fiqh tertentu mempunyai kecenderungan sesuai dengan aliran kalam yang dianutnya.

\section{KOMPONEN DAN KORELASI ALIRAN-ALIRAN DENGAN ILMU USHUL FIQH}

\section{Akal dan Ushul Fiqh}

Meskipun akal dan wahyu merupakan topik bahasan yang klasik (Abbas, 2010: 23-25), sampai hari ini masih tetap menarik dan relevan untuk dibicarakan, Edi Rosman mengatakan elaborasi nilai-nilai Islam itu harus dimanifestasikan kedalam hukum, dengan hukum itulah peranan Islam bersifat sentralistik. (edi, t.t: 28)

Dalam sejarah Islam masalah ini telah menjadi polemik yang tidak putus-putusnya, dikalangan ulamaulama Islam tidak saja di kalangan ahli kalam dan filosof, tetapi juga telah menjadi perbincangan ulama-ulama Ushul Fiqh.

Kata akal yang telah menjadi bahasa Indonesia berasal dari bahasa Arab (al-Aqlu) yang artinya adalah alatalat berpikir atau daya pikir untuk mengerti. Harun Nasution menjelaskan bahwa kata akal pada zaman jahiliyah dipakai dalam arti kecerdasan praktis (praktikal intelijent) yang dalam ilmu psikologi modern disebut dengan kecakapan untuk memecahkan masalah (problem solving capacity). (Harun, 1986: 7) Oleh karena itu orang yang berakal 
adalah orang yang memiliki kemampuan untuk menyelesaikan masalah apabila dia dihadapkan pada suatu problema dan selanjutnya ia dapat melepaskan diri dari bahaya yang ia hadapi.

Dalam perkembangan sejarah kata al-Aqlu (Abbas, 2010: 25) ini masuk pada filsafat Islam setelah terlebih dahulu dipengaruhi oleh filsafat Yunani sehingga diartikan dengan nous. Dalam filsafat Yunani kata nous mengandung arti yaitu daya pikir yang terdapat dalam jiwa manusia karena itu pemahaman dan pemikiran tidak lagi melalui al-Qolbu yang berada di dada tetapi melalui alAqlu yang ada di kepala. Sedangkan para teolog muslim mengartikan akal sebagai daya untuk memperoleh pengetahuan.

Abu Huzail seperti yang dikutip Harun Nasution mengartikan akal sebagai daya untuk memperoleh pengetahuan dan juga daya yang membuat seseorang dapat membedakan antara dirinya dan benda lain dan antara benda satu dengan benda lainnya, bahkan dalam pendapat sebagian tokoh Mu'tazilah akal diartikan sebagai petunjuk jalan bagi manusia dan membuat manusia menjadi pencipta perbuatannya sendiri.

Secara tegas Qadli Abdul Jabbar merumuskan akal itu sebagai sekumpulan ilmu tertentu yang apabila dimiliki oleh seorang mukallaf maka ia akan dapat berpikir mencari dalil dan melakukan apa yang ditaklukkan kepadanya (Husni, 1978: 31-32).

\section{Wahyu Dan Ushul Fiqh}

Sedangkan kata al-Wahyu yang
tetap dalam bahasa aslinya dapat

berarti isyarat, ilham, dan sebagainya. (Hasbi, 1977: 24) Kalangan teolog mengartikan wahyu sebagai pengetahuan yang didapat seseorang pada dirinya sendiri dengan keyakinan yang penuh bahwa pengetahuan itu datang dari Allah SWT, baik melalui perantara ataupun tidak melalui perantara. (Abduh, t.t: 108). Jadi, wahyu itu merupakan kebenaran yang datang dari Allah SWT, disampaikan kepada rasulnya. Maka apa yang disampaikan Allah SWT kepada Rasulnya ialah ajaran dan pedoman hidup bagi manusia untuk mencapai kebahagiaan dan kesejahteraan hidup di dunia dan di akhirat kelak.

Oleh karena itu persoalan berikutnya yang muncul adalah mengenai kedudu-kan akal dan fungsi wahyu bagi manusia sampai sejauh mana peranan akal dalam mengetahui adanya Tuhan dan kewajiban manusia untuk berterima kasih padanya. Apakah akal mampu untuk mengetahui kewajiban untuk melakukan yang baik dan kewajiban meninggalkan yang buruk.

Hal-hal yang dijelaskan di atas erat kaitannya dengan pembahasan masalah masalah teologi dalam Islam akan tetapi juga sering dibahas dalam hubungannya dengan masalah-masalah Syariah atau Ushul Fiqh.

Menurut pengamatan al-Syahrastani ada empat persoalan yang menjadi titik perhatian para ahli kalam dalam pembahasan mereka yaitu mengetahui adanya Tuhan dan kewajiban mengetahui adanya Tuhan, kemudian mengetahui baik dan buruk serta kewajiban mengerjakan per- 
buatan baik dan meninggalkan perbuatan buruk.

Hubungannya dengan persoalanpersoalan syariah, Abdul Wahab Khallaf mempertanyakan Apakah akal mampu untuk mengetahui ketentuanketentuan Allah baik berupa kewajiban atau larangan tanpa melalui wahyu atau tanpa rasul. (Wahhab Khallaf, 1970: 108) Jadi itu berkenaan dengan orang yang belum mendapat penjelasan dari seorang rasul atau disebut sebagai Ahlul Fatrah.

Secara umum al-Syahrastani menyebutnya sebagai orang yang belum mengetahui adanya Wahyu tentu saja bila dihadapkan pada masa sebelum datangnya Rasul yaitu pada masa fatrah atau bara'ah, maka jawabannya antara kelompok mu'tazilah, maturidiyah dan asy'ariyah terdapat perbedaan antara yang satu dengan yang lainnya.

Karena Mu'tazilah tidak mengakui adanya masa fatrah mereka menjelaskan bahwa di samping adanya mereka juga mengakui adanya. Oleh sebab itu akal mampu mengetahui tentang baik atau buruknya sesuatu maka tentu saja akibatnya adalah taklif saja yang melaksanakan taklif akan diberi pahala atau upah dan siapa saja yang meninggalkannya akan diberi siksa atau dosa.

Berbeda dengan Mu'tazilah meskipun Maturidiyah mengakui adanya masa fatrah, maka akal juga mampu untuk mengetahui hal yang baik atau buruk yang terdapat pada sesuatu karena kemampuan akal menurut Maturidiyah terbatas adanya maka tidak semua yang hal yang baik dan hal yang buruk dapat diketahui oleh akal. Namun demikian manusia berkewajiban melaksanakan hal-hal yang baik dan menjauhi hal-hal yang buruk menurut akalnya sedangkan urusan pahala dan dosa akal tidak mampu menetapkannya. Oleh sebab itu masalah tersebut diserahkan saja kepada rasul untuk menjelaskan atau menetapkannya.

Bagi Asy'ariyah karena mereka mengakui adanya masa fatrah dan tidak mengakui adanya maka akal tidak dapat mengetahui baik buruknya suatu perbuatan karena itu menurut Asy'ariyah tidak ada hukum atau taklif sebelum datangnya wahyu tidak ada pahala dan dosa tidak diberi pahala orang yang mengerjakan sesuatu dan tidak disiksa orang yang meninggalkan sesuatu pada masa fatrah atau pada masa Baraitul Ashliyah ini pada hakikatnya tidak ada keharusan untuk mengerjakan sesuatu atau meninggalkan sesuatu atau dengan kata lain boleh saja mengerjakan atau meninggalkan sesuatu.

Masalah yang timbul selanjutnya adalah bagaimana setelah datangnya wahyu apakah akal masih dapat atau diperbolehkan menetapkan sesuatu secara mandiri ataukah hanya berfungsi sebagai alat bantu untuk memahami apa yang tertuang di dalam nash atau wahyu apalagi secara literal wahyu memiliki keterbatasan dalam memuat persoalan-persoalan hukum apa lagi yang sifatnya terperinci.

Uraian yang agak panjang diberikan oleh Abdul Wahab Khallaf dalam kitab-nya, Mashadir al-Tasyri al-Islam fi Ma La nash fih, meskipun tulisan 
tersebut berkesan menolak kemampuan akal secara mandiri untuk menetapkan hukum-hukum yang tidak ada nash-nya. Mungkin pembahasan alSyatibi tentang Maqashid Syariah juga dapat menjawab persoalan dimaksud.

Dalam konteks ijtihad istinbath kerja akal memang dalam bentuk deduktif yaitu mengeluarkan apa makna yang terkandung di dalamnya sehingga kebebasan akal sedikit agak terbatas lain halnya ketika sudah memasuki lapangan ijtihad tathbiqi kemampuan akal sangat diperhatikan dan harus prima, jika tidak maka penerapan suatu hukum akan terasa tidak tepat bahkan mungkin tidak relevan. (Busyro, 2018: 167-170).

\section{TEORI MASING-MASING ALIRAN DALAM OPTIK ILMU USHUL FIQH}

Perbedaan masing-masing aliran dalam Ushul Fiqh beranjak dari pertanyaan besar, apakah hasil ijtihad ulama tersebut terbebas dari kesalahan dan seluruhnya adalah benar. Untuk menjawab persoalan ini dalam Ushul Fiqh ada 2 teori yang dikembangkan yaitu: taktiah (mukhattiah) dan tashwib (mushawwibah). (Busyro, 2017a: 29-31)

Takhtiah adalah pengakuan atas kemungkinan terjadinya kesalahan dalam keputusan keputusan hukum yang diambil oleh seorang mujtahid, sedangkan tashwib adalah penegasan bahwa hasil ijtihad seorang mujtahid tersebut tidak mungkin salah dan menolak kemungkinan adanya kesalahan itu.

Dalam kitab Ushul Fiqh umumnya dikatakan bahwa kelompok Syi ah cenderung dikelompokkan ke dalam kelompok mukhattiah karena menurut mereka kemungkinan adanya kesalahan dalam fatwa-fatwa mujtahid. Sedangkan mujtahid Sunni pada umumnya dikelompokkan kepada kelompok mushawwibah sehingga mereka percaya bahwa mujtahid itu selalu benar dalam mengambil keputusan-keputusan hukumnya.

Maka bagaimanapun juga bagi kaum Syìh yang mendefinisikan ijtihad sebagai upaya untuk mendeduksi hukum yang sejati dari sumber-sumber syariat sulit dibayangkan bahwa setiap mujtahid selalu benar akan tetapi dalam teori taswib yang berakar pada satu teori dilihat sebagai penggunaan qiyas dan rayu mereka menyatakan bahwa hukum Islam yang dijelaskan oleh nash jumlahnya terbatas sedangkan persoalan yang memerlukan ketetapan hukum jumlahnya tak terbatas. Oleh sebab itu Allah SWT memberikan kepada para ulama kebebasan untuk membuat ketetapan hukumnya.

Teori tashwib ini bertumpu pada pandangan yang menganggap bahwa tidak mungkin Allah SWT memberikan hukum-hukum secara sempurna semua persoalan, sebab bilamana demikian halnya tentu ditemukan semua jawabannya dalam al-Quran dan Sunnah, kenyataan-nya tidaklah demikian inilah yang memungkinkan wewenang yang diberikan Allah SWT kepada para ulama untuk digunakan semaksimal mungkin mencari jawabannya, hal ini juga berarti keputusan-keputusan yang diambil oleh para ulama merupakan hukum-hukum Allah SWT juga. (Busyro, 2017a: 54)

Betapapun kelemahan dari pendapat teori di atas yang jelas dalam hal yang tidak dijelaskan nash, akal dapat dijadikan sumber dalam pemecahan masalah hukum atau dengan kata lain dapat 
dikemukakan bahwa akal secara mandiri melalui jihadnya dapat menetapkan hukum pendapat tersebut diduga hanya dianut oleh mereka yang memberikan penghargaan yang tinggi kepada akal seperti Muhammad Abduh dan pendukung-pendukung Mu'tazilah.

Tentu tidak semua pendukung $M u ' t a z i l a h$ yang berpendirian demikian misalnya, Abu Husein al-Bashri alMu'tazili, dalam kitabnya al-Mu'tamad juz ke-2 secara panjang lebar berbicara tentang qiyas. Hal ini menunjukkan bahwa dia dan yang sepaham dengannya dalam hal memecahkan masalah-masalah hukum yang tidak ada nash nya tidak semata-mata berpegang kepada ketetapan akalnya akan tetapi melakukan analogi atau qiyas.

Sedangkan kelompok Syi`ah Imamiyah berpendapat bahwa akal dapat dijadikan sebagai dasar untuk menetapkan hukum akal mampu mengetahui yang baik dan yang buruk meskipun diakui akal memiliki keterbatasan. (alMughniyah, 1975: 262)

Jumhur ulama menolak penerapan hukum melalui akal secara mandiri, karena bagi jumhur hukum hanya dapat ditetapkan jika punya sandaran pada nash apakah itu langsung dari ketegasan nash maupun lewat makna nash, jika ada nash yang langsung maka dapat diamalkan namun bilamana tidak ada maka yang dilakukan adalah menetapkan nya lewat makna nash yaitu melalui qiyas, istihsan, maslahah, maupun istishab.

Dalam pandangan kelompok Mu'tazilah hukum-hukum syariat didasarkan kepada serangkaian manfaat dan mudharat yang nyata bahkan akal atau nalar manusia memiliki kemampuan secara mandiri untuk menemukan manfaat manfaat dan mudharat mudharat yang melekat pada sesuatu itu maka dengan sendirinya akal mampu menemukan maksud maksud dan kriteria-kriteria hukum agama melalui ijtihad dan rakyu.

Jadi bagi Mu'tazilah sebagai penganut paham teologi rasional berpendapat bahwa akal tanpa bantuan Rasul dan wahyu mampu mengetahui ketentuan-ketentuan hukum Allah SWT atas perbuatan manusia atau mukallaf. Hal ini disebabkan oleh adanya ciri-ciri khusus serta dampak positif dan negatif yang dimiliki oleh masing-masing perbuatan yang akan memudahkan akal untuk mengidentifikasi perbuatan tersebut.

Bagi Mu'tazilah jauh sebelum turunnya wahyu atau andai kata wahyu tidak turun, manusia tetap dituntut untuk mengetahui adanya Tuhan dan berterima kasih kepadanya manusia juga dituntut untuk mengetahui kebaikan dan kejahatan dan untuk itu mereka memberlakukan prinsip al-Wa'du wa al-waid, siapa yang berbuat baik akan diberi pahala dan siapa yang berbuat jahat akan diberi siksa.

Begitu besarnya peranan akal bagi kelompok Mu'tazilah ini maka mereka menempatkan akal sebagai sumber pertama syariat karena baginya dengan akal dapat diketahui yang baik dan yang buruk juga dapat diketahui kehujahan alQuran dan Sunnah, sedangkan bagi Qadli Abdul Jabbar menyatakan bahwa akal memang mampu mengetahui kewajibankewajiban secara umum akan tetapi akal tidak sanggup mengetahui perinciannya baik mengenai hidup manusia di dunia bahkan di akhirat kelak, maka wahyu 
Allah SWT yang menjelaskan bagaimana cara shalat, cara puasa, cara berzakat, cara haji, dan sebagainya.

Berdasarkan uraian di atas dapat disimpulkan bahwa dalam aliran-aliran teologi memiliki pertimbangan yang berbeda antara peranan akal dan fungsi wahyu, maksudnya semakin besar fungsi wahyu dalam satu aliran maka bertambah kecillah peranan akal dalam satu aliran, sebaliknya semakin besar peranan akal dalam satu aliran maka semakin kecil lah fungsi wahyu dalam aliran tersebut jadi peranan akal berbanding terbalik dengan fungsi wahyu, dan hal ini juga yang akan membawa implikasi pada sistem pengambilan keputusan hukum yang mereka gunakan dengan membicarakan kedudukan akal dan wahyu. (Abbas, 2010: 25)

\section{MACAM-MACAM ALIRAN DAN PENGARUHNYA DALAM ILMU USHUL FIQH}

Beberapa aliran dalam Ushul Fiqh lahir sejak abad ke-2 Hijriyah (Wahhab Khallaf, 1978: 16) berangkat dari keadaan pada awal abad Hijriyah ini tidak diperlukan karena keberadaan Rasulullah masih bisa mengeluarkan fatwa dan menetapkan suatu hukum berdasarkan Wahyu yang ia terima disamping sunnah beliau sendiri. Disamping itu sejatinya ijtihad Rasul tidak membutuhkan Ushul Fiqh atau kaidah-kaidah yang dapat membantu beliau melakukan istinbath dan ijtihad.

Ketika dunia Islam sudah semakin meluas mereka tidak lagi hanya terdiri dari kalangan bangsa Arab jumlahnya sudah semakin banyak. Hal ini menyebabkan terjadinya asimilasi kebudayaan, interaksi sosial, serta pencampuran dan penyerapan bahasa akibatnya pemahaman terhadap teks mulai dipengaruhi oleh perkembangan masyarakatnya tersebut. Hal inilah yang mendorong munculnya kebutuhan akan batas-batas dan kaidah bahasa yang dapat mendukung pemahaman al-Nushush agar pembangunan tersebut tetap pada maksudnya semula inilah yang mendorong lahirnya ilmu Ushul Fiqh.

Ilmu ini berkembang dengan pesat bersamaan dengan pesatnya perkembangan hukum Islam atau fiqh karena setiap Imam Mujtahid selalu memberikan petunjuk dengan dalil hukum yang disertai metodologi atau Ushul Fiqh secara berkesinambungan, mereka menyusun ilmu ini dengan uraian yang panjang lebar, juga ada yang membuat secara ringkas para ulama kalam meniru caracara dan metode serta sistem yang dikembangkan ilmu ini namun ulama Hanafiyah menempuh cara lain dalam penyusunan ilmu Ushul Fiqh mereka. (Wahhab Khallaf, 1978: 17-20)

Ketidaksepakatan para ulama dalam menggunakan istilah-istilah dan cara-cara yang ditempuh dalam pembahasan Ushul Fiqh telah melahirkan corak pandangan atau aliran dalam Ushul Fiqh sekurangkurangnya pada abad ke-5 dan ke-6 Hijriyah telah muncul tiga aliran pemikiran Ushul Fiqh, yaitu; (Khudari Bek, 1969: 6 dan 9) Aliran Mutakallimin; Aliran Fuqaha; dan Aliran Gabungan. (Busyro, 2017b: 44-47)

Berikut adalah gambaran bagaimana cara pandang, serta konsep apa yang ditawarkan oleh masing-masing aliran, sehingga mempengaruhi kajian ilmu Ushul Fiqh: (Abbas, 2010: 15-20) 


\section{Aliran Mutakallimin}

Ulama kalam dalam metode berpikirnya banyak menggunakan kaidah-kaidah, kemudian ulama-ulama Ushul menyertakan penelitian dan pembuktian atas kaidah-kaidah dalam pembahasan ilmu ini secara logis, rasional, dan teoritis. Menekankan pada pembuktian kaidah terhadap hukum-hukum yang telah di istinbathkan oleh para mujtahid sebelumnya namun lebih bertumpu pada apa yang dinilai rasional dan terdapat dalilnya. Maka itulah yang disebut sumber pokok syariat Islam, apakah itu relevan atau tidak relevan dengan masalah furu itu tidak menjadi masalah sebagian besar ulama yang menggunakan pendekatan seperti ini adalah ulama ulama SyafI'iyah dan Malikiyah.

Dalam pembahasan kaidahkaidah Ushuliyah aliran ini berpegang pada analisis-analisis kebebasan atau linguistik dan analisis terhadap illatillat hukum cara yang mereka tempuh cenderung memakai cara yang ditempuh oleh ulama-ulama kalam artinya kaidah-kaidah yang ditetapkan ditopang dengan alasan-alasan yang kuat baik dengan nash maupun dengan logika atau mantiq tanpa terikat dengan hukum-hukum huruf yang telah ada dalam satu mazhab, sehingga menyebabkan pembahasan mereka lebih bersifat teoritis.

Para ulama aliran ini dalam pembahasannya menggunakan caracara yang digunakan dalam ilmu kalam yakni dalam menetapkan kaidah ditopang dengan alasan-alasan yang kuat baik naqli maupun aqli tanpa terikat dengan hukum-hukum yang telah ada dalam mashab manapun sesuai atau tidak sesuai nya suatu kaidah dengan hukum-hukum tersebut tidak menjadi persoalan aliran ini diikuti oleh para ulama dari golongan Mu'tazilah, Malikiyah dan Syafi'iyah. (Mukhtar dkk, 1995: 17)

Kelompok ini dikenal dengan aliran Ushul Safi'iyah karena mereka mengikuti jalan pikiran Imam Syafi'i dalam mengembangkan kaidah dan menerapkannya aliran ini (A. Zahrah, 1958: 20) dikenal pula dengan aliran Mutakallimin karena ulama-ulama ilmu kalam umumnya membicarakan pokok masalah mereka menurut cara teori ini akibat lain dari ketidakterikatan mereka dengan hukum-hukum furu menyebabkan terjadinya perbedaan pendapat di kalangan mereka sendiri, bahkan mereka berbeda pendapat dengan Syafi'i (al-Amidi, 1968: 6) sebagai perintis aliran ini.

Kelompok ini mengembangkan Ushul Fiqh teoritik dimana hukum fiqh mereka harus dibangun dan tunduk pada teori yang mereka bangun mereka membuat kaidah atau norma yang tidak diambil dari hukum fiqh mereka yang sudah ada baik untuk mempertahankan maupun untuk merevisi pendapat mereka perbedaannya dengan imam Syafi'i antara lain terlihat dalam kaitannya dengan pemakaian ijma sukuti. Bagi Imam Syafi'i ijma sukuti tidak dapat dijadikan hujjah, sedangkan al-Amidi (pengikut Imam Syafi'i) dapat dijadikan hujjah Syara akan tetapi nilainya tidak sama dengan ijma' Syarih. 
Jika dicermati lebih jauh maka Imam al-ghazali berpendapat bahwa perbedaan tersebut terlihat pada penggunaan pendapat sahabat (qaul shahaby). Imam Syafi'i baik dalam kitab risalahnya maupun dalam kitab alUmm menyatakan bahwa pendapat sahabat dapat digunakan sepanjang tidak ditemukan dalil al-Quran, sunnah maupun ijma'. (Wahhab Khallaf, 1978: 261) Dalam hal ini penulis berpendapat bahwa pendapat sahabat itu termasuk ke dalam kelompok lapangan ijtihadiah karenanya kita boleh berbeda pendapat dengannya, bahkan boleh meninggalkannya.

Adanya perbedaan pendapat di atas menunjukkan bahwa para ulama Ushul Fiqh dari kalangan Syafi'iyah maupun mutakallimin ini menciptakan kaidah-kaidah Ushul Fiqh semata-mata karena tuntutan ilmiah sehingga mereka melakukan langkah-langkah atau kerangka berfikir deduktif, dalam kaitan ini Imam al-Haramain menyatakan bahwa dalam membahas Ushul Fiqh tidak perlu melihat masalah furu akan tetapi masalah furu itu dapat dikoreksi dan diukur dengan Ushul bukan dengan furu.

Hal ini ditegaskan pula oleh Imam Al Ghazali bahwa dalam Ushul Fiqh tidak dibicarakan masalah-masalah furu melainkan hanya dalil-dalil syara seperti al-Kitab, baik dari segi mantuq maupun dari segi mafhumnya termasuk logikanya tanpa mengungkap masalah buruk secara khusus.

Namun demikian aliran Ushul Mutakallimin ini tetap mempelajari masalah fiqhiyah terlebih dahulu sebelum mempelajari Ushul hal ini setidak-tidaknya untuk mengetahui metode istinbath mereka Qadli Abu Ya'la menegaskan bahwa, seseorang tidak boleh meneliti Ushul sebelum meneliti orang yang belum menguasai furu' akan sulit mengetahui istinbath Ushul.

Kelemahan dari aliran Ushul Mutakallimin ini adalah bahwa pemikiran mereka kurang langsung menyentuh persoalan atau realitas sosial masyarakat mereka banyak membakukan pengandaian akan tetapi dari segi pengembangan teori keilmuan maka cara pandang mereka sangat menunjang perkembangan ilmu Ushul Fiqh itu sendiri. Kajian-kajian teoritik yang mereka lakukan dapat membantu ulama-ulama untuk melakukan penggalian penggalian hukum dan rekayasa hukum pada masa-masa mendatang.

\section{Aliran Fuqaha}

Aliran Ushul ini bertitik tolak dari kasus-kasus konkrit yang muncul atau bertitik tolak dari hukum-hukum furu yang diterima dari Imam-imam mazhab mereka, kaidah-kaidah Ushul mereka disusun berdasarkan hukumhukum furu apabila terdapat pertentangan dengan hukum hukum furu maka kaidah itu harus diubah sedemikian rupa sehingga sesuai dengan hukum tersebut.

Besarnya perhatian para ulama fuqaha ini terhadap masalah-masalah furu terlihat dalam dua aspek teknik perumusan kaidah Ushul sistematika penulisan kitab-kitab Ushul. Dalam merumuskan kaidah-kaidah Ushul ulama Hanafiyah terlebih dahulu mengadakan penelitian terhadap masalah furu dan fatwa-fatwa ulama mereka melakukan pengkajian terhadap makna 
yang terkandung serta mengambil prinsip-prinsip umum dari masalah tersebut setelah itu baru mereka berupaya untuk menjadikannya sebagai kaidah-kaidah Ushul.

Cara pandang atau langkahlangkah seperti ini sering disebut cara berpikir Induktif, gambaran dari cara berpikir seperti tersebut di atas terlihat pada cara pandang ulama-ulama Hanafiyah seperti halnya al-Jashash, alDabusi, al-Haraki dan lainnya. Mereka membicarakan dan mengembangkan kaidah-kaidah Ushul mereka untuk digunakan dalam fiqh madzhab mereka baik untuk mempertahankan maupun untuk mengembangkannya kaidah yang mereka susun ini harus tunduk kepada fiqh atau fatwa Imamimam mereka orang pertama yang merumuskan dan menggunakan cara ini adalah Imam Abu Hanifah sehingga aliran ini juga dikenal Ushul Hanafiyah meskipun untuk pertama kali Ushul Fiqhnya belum tertulis namun para ulama pendukung aliran ini memahami dan menghafal cara ini.

Pada mulanya kaidah yang mereka buat itu sifatnya sederhana saja yaitu dalam rangka mempertahankan fatwa Imam dan pendirian mazhab mereka namun dalam kenyataannya dan pengembangannya pengaruhnya sangat besar sekali pemikiran fiqh secara umum. Jadi para ulama dalam aliran ini selalu menjaga persesuaian antara kaidah hukum dengan hukum yang diterima dari imam-imam mereka.

Untuk lebih jelasnya sebagai bahan kajian dapat dicermati contoh, kitab al-Fushul fi al-Ushul karya al-
Jashash. Kitab ini merupakan kitab Ushul yang dijadikan pengantar kitab tafsir Ahkam al-Quran. Kitab ini juga dianggap sebagai kitab fiqh Hanafiyah yang orisinil demikian pula kitab Ushul al-Sarakhsi. Dalam kitab ini ditemukan penjelasan tentang pokok-pokok masalah yang terdapat dalam kitabkitab fiqh yang disusun oleh alSyaibani sendiri menyatakan bahwa tujuan penulisan Ushulnya adalah untuk menjelaskan pokok-pokok masalah yang mendasari kitab fiqh yang disusun oleh al-Syaibani.

Untuk melihat perbedaan yang menonjol antara aliran Ushul Mutakallimin dengan aliran Ushul Fuqaha, sekurang-kurangnya dapat dianalisis dari tiga aspek:

a. Aspek al-Taksis (formulasi akidah),

b. Aspek al-Manhaj (metodologi),

c. Aspek al-Tafkir (pemikiran).

Dalam memformulasikan kaidah Ushul ada kecenderungan aliran Ushul Mutakallimin berpegang kepada pemahaman Ushul bahasa dalil-dalil naqli dan aqli sedangkan aliran Fuqaha ada kecenderungan memformulasikan kaidah nya dengan mengaitkannya dengan masalah-masalah. Dari segi metode ulama Ushul Mutakallimin menggunakan pola berpikir deduktif artinya memuat kaidah yang dapat dijadikan sebagai acuan dalam menetapkan hukum-hukum, sedangkan aliran Ushul fuqaha mempergunakan pola pikir induktif artinya melakukan penelitian hukum-hukum furu' terlebih dahulu baru kemudian melahirkan kaidah.

Ushul Fiqh aliran Mutakallimin merupakan aturan-aturan istinbath 
yang bersifat menetapkan sedangkan Ushul Fiqh aliran fuqaha tidak bersifat menetapkan, karena ditentukan oleh perbedaan itu tidak hanya terlihat pada cara istinbath akan tetapi juga dalam sistematika pembahasan kitab-kitab Ushul mereka.

Aliran Ushul Mutakallimin mengawali pembahasannya dari segi kebahasaan, semantik, dan tentang dalildalil syara', dengan mengembangkan gagasan-gagasan kitab ar-Risalah asSyafi i aliran ini menjadi aliran utama dalam Ushul Fiqh (Effendi \& Zein, 2009, hlm. 24), sedangkan aliran Ushul Fuqaha memulai bahasan dengan mengungkapkan dalil-dalil syara', persyaratan ijtihad, dan pertanggungjawaban manusia.

Model pendekatan aliran mutakallimin ini dapat dilihat misalnya pada Imam al-Ghazali dalam kitabnya alMustashfa dan model Ushul fuqaha misalnya dapat dilihat pada alBazdawy. Dalam kitabnya Kanz alWushul Ila Ma`rifah al-Ushul.

Dari aspek pemikiran yaitu yang menyangkut tentang penilaian kehujahan suatu dalil atau pemahaman terhadap hujjah tersebut. Maka antara aliran Ushul Mutakallimin dan aliran Ushul Fuqaha terdapat perbedaan dalam beberapa hal antara lain:

a. Tentang Dalalah lafaz `am,

b. Lafaz Muthlaq,

c. Lafaz Muqayyad,

d. Mafhum Mukallaf,

e. Hadits Mursal dan Khabar Ahad.

\section{Aliran Gabungan (al-Jam`u)}

Dengan adanya kedua aliran Ushul tersebut di atas pembahasan ilmu Ushul Fiqh menjadi semakin menarik dan ramai dibicarakan dikalangan para ulama dalam semua mazhab dan aliran para ulama masingmasing mazhab yang empat sama-sama bergiat dan berlomba mengembangkan cara dan alian yang mereka anut.

Mazhab Zhahiri dan Syiahpun tertarik berbicara tentang Ushul fikih ini karena hal tersebut menyangkut masalah yang erat hubungannya dengan mempertahankan atau mengembangkan fiqh madzhab mereka. Di samping itu ada lagi ulama yang berusaha mengkombinasikan pendekatan kedua aliran Ushul tersebut seperti misalnya yang dilakukan Ahmad bin Ali al-Sa`aty al-Baghdadi dengan kitab Badia' al-Nizamnya.

Jadi ajaran Ushul gabungan ini muncul setelah munculnya dua aliran Ushul sebelumnya berusaha untuk memadukan kedua corak pemikiran Ushul dari kedua aliran tersebut dalam menetapkan kaidah-kaidah Ushul-nya mereka mengemukakan alasan-alasan yang kuat dan juga memperhatikan persesuaian nya dengan hukumhukum huruf yang telah ada.

Aliran Ushul ini dalam uraianuraiannya berupaya untuk mengemukakan pendapat-pendapat ulama baik ulama Ushul Mutakallimin maupun Ushul Fuqaha dengan mengutamakan alasan dan argumentasi masing-masing pendapat, kemudian mereka analisis secara cermat dan objektif tanpa apriori pada salah satunya kemudian dipenghujung analisisnya. Mereka kemudian mengemukakan pendapat mereka sendiri lengkap dengan argumentasi dan dalil yang mereka pergunakan cara seperti 
ini misalnya dilakukan oleh al-Sa`ady, Ibnu Subky, dan Ibnu Humam.

\section{KESIMPULAN}

Berdasarkan penjelasan pada bahasan di atas, maka dapat dismpulkan bahwa Sejarah lahirnya aliran-aliran dalam Ushul Fiqh dimulai sejak abad ke dua Hijriyah, persis pasca wafatnya Nabi Muhammad SAW. Muncul dan berkembangnya aliran-aliran dalam Ushul Fiqh ini beranjak dari konflik politik yang berkelanjutan hingga pemahaman teologi dan fiqh. Oleh karena itu, khilafiah dalam teori Ushul Fiqh adalah keniscayaan bagi umat Islam dan kaya akan ijtihadiyah hal ini dimulai dari kepemimpinan Abu Bakar Ash-Siddiq selaku pelanjut estafet kepemimpinan Nabi.

Dalam perkembangannya perbedaan dalam memahami nash atau dalil dalam menjawab persoalan mukallaf bagi umat Islam mengerucut pada tiga aliran populer, yaitu aliran Mutakallimin, aliran Fuqaha, dan aliran al-Jam`u (Gabungan), dan yang ketiga, pengaruh aliran-aliran dalam Ushul Fiqh adalah berkaitan erat dengan proses dan hasil hukumnya, karena Ushul Fiqh sebagai ilmu dasar dalam menemukan hukum sangat menentukan konstruksi hukum yang dimaksud, sehingga penentuan aliran Ushul Fiqh yang tepat akan berbanding lurus dengan kekuatan konstruksi hukum itu sendiri.

\section{DAFTAR PUSTAKA}

Abbas, A. F. (2010). Baik dan Buruk Dalam Perspektif Ushul Fikih (1 ed.). adelina Bersaudara.

Abduh, M. (t.t.). Risalah Tauhid. al-Manar.
al-Mughniyah, al-J. (1975). Ilm Ushul Figh fi Tsaubih al-Jadid. Dar al-Ilm li alMalayyin.

al-Amidi. (1968). Al-Ihkam fi Ushul alAhkam (Vol. 1). Maktabah Ali Subaih.

al-Zuhaily. (2002). Al-Figh al-Islami wa Adillatuhu. Dar al- Fikr al-Ma`asir.

Amin, M. S. (2014). Judicial Review Tap MPR RI Terhadap Undang-Undang Dasar (UUD) 1945 Menurut Jimli Assdiddiqie. Al-daulah: jurnal hukum dan perundangan islam, 4(1).

Bay, K. (2012). Metode Mengetahui 'Illat dengan Nash (Al-Qur'an dan Sunnah) dalam Qiyas. Jurnal Ushuluddin, XVIII(2), 141-154.

Busyro. (2009). Pemikiran Hukum dan Fatwa Abdullah ibn Mas'ud. AlHurriyah, 10(2), 22-33.

Busyro. (2014). Abdullah Ahmad AnNa'im Dan Konsep Pemikiran Hukum Liberalisnya. Al-Hurriyah, 15(2), 44-56.

Busyro. (2017a). Dasar-Dasar Filosofis Hukum Islam. WADE.

Busyro. (2017b). Maqashid al-Syariah. WADE.

Busyro. (2018). Eksistensi 'Illat dalam Mengukuhkan Teks Hadis-hadis Ru'yat al-Hilāl dan Fungsinya dalam Pengembangan Hukum Islam. AlAhkam, 28(2), 167-192.

Edi. (t.t.). Legislasi Hukum Islam di Indonesia (Sejarah Dan Relevansi Praktis Pembaharuan Hukum Nasional).

Effendi, S., \& Zein, M. (2009). Ushul Figh (Vol. 3). Interpratama Offset. 
Hakiki, K. M. (2016). Islam dan Demokrasi: Pandangan Intelektual Muslim dan Penerapannya di Indonesia. Jurnal Ilmiah Agama dan Sosial Budaya, 1(1), 1-17.

Harun, N. (1986). Akal dan Wahyu Dalam Islam. UI Press.

Hasbi, al-S. (1977). Sejarah Pengantar Ilmu al-Quran/ Tafsir. Bulan Bintang.

Husni, Z. (1978). Al-Aql inda al-Mu`tazilah. Dar al-Afaq al-Jadidah.

Imron, A. (2008). Transformasi Hukum Islam Ke Dalam Hukum Nasional Di Indonesia. Jurnal Hukum Dan Dinamika Masyarakat, 5(2), 1.

Ismail. (2016). Eksistensi Rakyu Dalam Pengembangan Hukum Islam. Alhurriyah: Jurnal Hukum Islam, 01(01), 45-54.

J. Moleong, L. (1989). Metodologi Penelitian Kualitatif. PT Remaja Rosdakarya.

Khudari Bek, M. (1969). Ushul al-Figh. Dar al-Fikr.

Malarangan, H. (2008). Pembaruan Hukum Islam dalam Hukum Keluarga di Indonesia. Jurnal Hunafa, $5(1), 40$.

Mth, A. (2005). Studi pemikiran alMaqashid (Upaya Menemukan Fondasi Ijtihad Akademik yang Dinamis). Al-Mawarid, XIV, 155-173.
Mukhtar dkk, K. (1995). Ushul Fikih. Dana Bakti Wakaf.

Rusli, N. (1999). Konsep Ijtihad AsySyaukani. Logos.

S Elwa, M. (1983). On The Political System Of Islam.

Sabiq, A.-S. (1977). Fiqh al-Sunnah. Dar alFikr.

Suherman, M. (t.t.). Aliran Ushul Fiqh dan Maqashid Syari'ah. al Mashlahah Jurnal Hukum dan Pranata sosial Islam.

Tafsir Ibnu Katsir. (2015). Ibnu Katsir Online.com.

Toriquddin, M. (2014). Teori Maqâshid Syarî'ah Perspektif al-Syatibi. Jurnal Syariah dan Hukum, 6(1), 34.

Wahhab Khallaf, A. (1970). Ilmu Ushul alFigh. Dewan Dakwah Islamiyah Indonesia.

Wahhab Khallaf, A. (1978). Ilmu Ushul alFigh (12 ed.). Dur al- Qalam.

Zahrah, A. (1958). Ushul al-Figh. Dar alFikr al-Arabi.

Zahrah, M. A. (1996). Aliran Politik dan 'Aqidah dalam Islam (Abd. R. Dahlan \& A. Qarib, Penerj.). Logos. 